\title{
KINERJA BIDANG KEBERSIHAN DAN PERTAMANAN DINAS TATA RUANG PEMUKIMAN DAN KEBERSIHAN DALAM MENANGANI SAMPAH DI KABUPATEN SUBANG
}

\author{
Oleh : \\ Luki Natika \\ Fakultas Ilmu Administrasi Universitas Subang \\ email : luckynatika@gmail.com
}

\begin{abstract}
ABSTRAK
Bidang Kebersihan dan Pertamanan sebagai salah satu pihak yang bertanggung jawab dalam kebersihan dan keindahan Kabupaten Subang, sudah menjadi kewajiban untuk menciptakan kebersihan dengan kinerja yang optimal. Namun kendala yang dihadapi saat ini adalah belum optimalnya Kinerja Bidang Kebersihan dan Pertamanan Dinas Tata Ruang Permukiman dan Kebersihan dalam Menangani Sampah di Kabupaten Subang secara keseluruhan.

Tujuan dilakukannya penelitian ini adalah untuk mengetahui apakah Kinerja Bidang Kebersihan dan Pertamanan Dinas Tata Ruang Permukiman dan Kebersihan dalam Menangani Sampah di Kabupaten Subang sudah berjalan dengan baik atau tidak dan untuk mengetahui unsur-unsur apa saja yang menjadi kendala Kinerja Bidang Kebersihan dan Pertamanan Dinas Tata Ruang Permukiman dan Kebersihan dalam Menangani Sampah di Kabupaten Subang.

Metode yang digunakan dalam penelitian ini adalah menggunakan pendekatan kualitatif dengan metode analisis deskriptif dengan teknik Snowball Samping, yaitu proses penentuan informan berdasarkan informan sebelumnya tanpa menentukan jumlahnya secara pasti dengan menggali informasi terkait topik penelitian yang diperlukan. Informan yang diambil adalah Kepala Bidang Kebersihan dan Pertamanan, Kepala Seksi Operasional, Kepala Seksi Persampahan, dan Masyarakat. Teknik pengumpulan data meliputi wawancara dan observasi.

Berdasarkan penelitian, diperoleh hasil bahwa Kinerja Bidang Kebersihan dan Pertamanan Dinas Tata Ruang Permukiman dan Kebersihan dalam Menangani Sampah di Kabupaten Subang secara umum belum optimal. Unsur-unsur yang mempengaruhi keberhasilan Kinerja Bidang Kebersihan dan Pertamanan Dinas Tata Ruang Permukiman dan Kebersihan dalam Menangani Sampah di Kabupaten Subang adalah sarana dan prasarana, kondisi geografis dan jumlah penduduk serta pertisipasi masyarakat.
\end{abstract}

\footnotetext{
Kata Kunci : Kinerja Bidang Kebersihan dan Pertamanan Dinas Tata Ruang Permukiman dan Kebersihan dalam Menangani Sampah di Kabupaten Subang
} 


\begin{abstract}
Field of Hygiene and as one of the parties responsible for the cleanliness and beauty of Subang district, has become a liability to create a cleanliness with optimal performance. However, the constraints faced today is not optimal and Sanitation Sector Performance Spatial Planning Settlement and Hygiene in Waste Handling in Subang overall.

The purpose of this study was to determine whether the Performance Division of Hygiene and Spatial Planning Settlement and Hygiene in Handling Garbage in Subang district is already running well or not and to determine what elements are an obstacle Performance Sector and Sanitation Department of Spatial Planning settlement and Hygiene in Waste Handling in Subang.

The method used in this research is using qualitative approach with descriptive analysis method with Snowball engineering side, ie the process of determining the informants based on previous informant without specifying exact numbers by exploring related information necessary research topics. Informants taken was Head of Cleanliness and Landscaping, Head of Operations Section, Section Head of Waste, and Society. Data collection techniques include interviews and observation.

Based on research, the result that performance and Sanitation Sector Department of Housing and Spatial Planning in the Hygiene Handle Waste in Subang district is generally not optimal. The elements that affect the success and Sanitation Sector Performance Spatial Planning Settlement and Hygiene in Waste Handling in Subang is infrastructure, geography and population and public participation.
\end{abstract}

Keywords : Performance Sector and Sanitation Department of Housing and Spatial Planning in the Hygiene Handle Waste in Subang

\section{PENDAHULUAN}

Pembangunan dan kemajuan suatu kota ditandai dengan adanya berbagai kegiatan dan aktivitas yang beragam, seperti kegiatan pembangunan sarana dan prasarana publik, ditambah lagi kegiatan pembangunan permukiman yang pesat, serta beragamnya aktivitas yang dilakukan masyarakatseperti aktivitas rumah tangga, perekonomian, dan sebagainya. Sejalan dengan berkembang pesatnya pembangunan tersebut akan memberi konsentrasi terhadap kebutuhan sarana dan prasarana sehingga tercipta suatu kota yang nyaman dan tertata. Permasalahan sampah sudah menjadi persoalan serius terutama di kota-kota besar, tidak hanya di Indonesia saja, tapi di seluruh dunia.Negara-negara maju telah melakukan berbagai upaya untuk mengatasi masalah tersebut, 
begitupun bagi Pemerintah Daerah dimana masalah persampahan merupakan masalah serius. Produksi sampah yang terus menerus meningkat seiring dengan pertumbuhan penduduk yang tinggi, perubahan pola konsumsi, dan gaya hidup masyarakat telah meningkatkan jumlah timbulan sampah yang semakin banyak. Meningkatnya volume timbulan sampah memerlukan pengelolaan sampah.Pengelolaan sampah dimaksudkan adalah kegiatan yang sistematis, menyeluruh, dan berkesinambungan yang meliputi pengurangan dan penanganan sampah.Pengelolaan sampah bertujuan untuk meningkatkan kesehatan masyarakat dan kualitas lingkungan yang bersih serta sehat.Volume timbulan sampah yang semakin banyak, harus adanya pengelolaan sampah, salah satu pengelolaannya dengan tersedianya tempat pembuangan akhir (TPA) sampah.

Dinas Tata Ruang Permukiman dan Kebersihan adalah organisasi yang dibentuk berdasarkan Peraturan Kabupaten Subang Nomor 14 Tahun 2008 tentang Tugas Pokok dan Fungsi Dinas Tata Ruang Permukiman dan Kebersihan Kabupaten Subang yaitu melaksanakan sebagian kewenangan Pemerintah Daerah di bidang kebersihan penataan ruang, permukiman dan kebersihan serta tugas pembantuan yang diberikan oleh Pemerintah atau Pemerintah Provinsi Jawa Barat. Dinas Tata Ruang Permukiman dan Kebersihan juga dibentuk berdasarkan Undangundang No 18 Tahun 2008 tentang Pengelolaan Sampah. Bidang kebersihan sebagai salah satu pihak yang bertanggung jawab dalam kebersihan dan keindahan Kabupaten Subang, sudah menjadi kewajiban untuk menciptakan kebersihan lingkungan dengan kinerja yang optimal.Namun, kenyataannya masih ditemui adanya keluhan-keluhan dari masyarakat yang berkaitan dengan sampah.

Kondisi penanganan sampah di wilayah Kabupaten Subang memang masih kurang.Dalam kaitannya dengan pengelolaan persampahan, Kabupaten Subang memiliki volume sampah yang banyak.Salah satunya penyebab volume sampah yang banyak dan menumpuk diakibatkan karena tidak terangkutnyasampah oleh kendaraan pengangkutan sampah.Bidang kebersihan dan Pertamanan Kabupaten Subang hendaknya lebih meningkatkan kinerja agar mampu menciptakan kebersihan dan keindahan Kabupaten Subang. Dengan jumlah penduduk Kabupaten Subang tahun 2014 adalah 1.677.790 jiwa, luas wilayah kurang lebih 205.176,95 ha dan diperkirakan menghasilkan jumlah sampah 1.677.794 meter kubik perhari yang dihasilkan hanya bisa dikelola sebanyak 974.985 meter kubik. Maka selisih sampah yang tidak bisa dikelola 702.809 meter kubik. Dengan ditangani 24 unit armada kendaraan angkut, diantaranya 15 unit armada kendaraan difokuskan beroperasi mengangkut sampah di wilayah pusat Kota Kabupaten Subang dikarenakan produksi sampah warga Subang paling tinggi, sedangkan 9 unit armada kendaraan disebar di sembilan kecamatan yang produksi sampahnya tinggi, yaitu 
Kecamatan Subang, Ciasem, Patokbeusi, Purwadadi, Kalijati, Pagaden, Blanakan, Pabuaran, Cipunagara dan Pamanukan. Kinerja merupakan merupakan hasil dari serangkaian proses kegiatan yang dilakukan untuk mencapai tujuan tertentu organisasi. Sedangkan kinerja organisasi merupakan tingkatan sejauh mana organisasi dapat mencapai tujuan yang didasarkan pada tujuan yang sudah ditetapkan sebelumnya.Bagi suatu organisasi, kinerja merupakan hasil dari kegiatan kerjasama diantara anggota atau komponen organisasi dalam rangka mewujudkan tujuan organisasi. Kinerja suatu organisasi dapat dilihat dari tingkatan sejauh mana organisasi dapat mencapai tujuan yang didasarkan pada visi dan misi yang sudah ditetapkan sebelumnya. Untuk itu, diperlukan beberapa informasi tentang kinerja organisasi.informasi tersebut dapat digunakan untuk melakukan evaluasi terhadap proses kerja yang dilakukan organisasi selama ini, sudah sejalan dengan tujuan yang diharapkan atau belum. Faktanya, banyak organisasi tidak mempunyai informasi tentang kinerja dalam organisasinya. Dari definisi diatas dapat dipahami bahwa kinerja organisasi adalah seberapa jauh tingkat kemampuan pelaksanaan tugas-tugas organisasi dalam rangka pencapaian tujuan sesuai dengan kemampuan yang dimiliki dan program/ kebijakan/ visi dan misi yang telah ditetapkan sebelumnya.Pengertian Kinerja dalam organisasi merupakan jawaban dari berhasil atau tidaknya tujuan organisasi yang telah ditetapkan.Para instansi sering tidak memperhatikan kinerja instansi atau organisasi kecuali kinerja sudah amat buruk.
Secara umum kebijakan pengelolaan sampah di Kabupaten Subang merupakan Tugas Pokok dan Fungsi Dinas Tata Ruang Permukiman dan Kebersihan (Distarkimsih).Pengelolaannya masih mengikuti paradigma lama, dimana sampah di kumpulkan, kemudian diangkut dan akhirnya dibuang ke tempat pembuangan akhir Panembong Subang. Jumlah sampah yang terangkut ke TPA Panembong ini hanya bisa diangkut $21 \%$ karena kendaraan angkutan sampah yang masih kurang, serta TPA Panembong hanya bisa menampung sebanyak kurang lebih 186 meter kubik perhari. Dalam upaya membantu peran Bidang Kebersihan dan PertamananDinas Tata Ruang Permukiman dan Kebersihan menangani sampah maka Pemerintah Kabupaten Subang telah berupaya meningkatkan pelayanan kepada masyarakat dalam bidang kebersihan, dalam upaya pencapaian kota yang bersih, sehat, rapi dan indah. Sehingga fungsi bidang kebersihan pertamanan dalam pengelolaan persampahan di Kabupaten Subang untuk menciptakan Subang bebas sampah dengan upaya efektif dan efisien mulai dari tahap pewadahan, pengumpulan, pengangkutan, hingga tahap pembuangan akhir dapat tercapai.

Berdasarkan hasil penelitian pada Dinas Tata Ruang Permukiman dan Kebersihan Kabupaten Subang bahwa kinerja bidang kebersihan atau persampahan masih rendah, hal tersebut dapat dideteksi dari indikasi sebagai berikut :

1. Volume sampah yang semakin banyaktidak diimbangi dengan peningkatan jumlah sarana dan 
prasarana persampahan sehingga berdampak pada tingkat pelayanan dari pengelolaan sampah yang rendah. Hal ini dilihat dari volume sampah yang dihasilkan perhari 1.677 .794 meter kubik, sampah yang bisa terangkut 974.985 meter kubik/hari.

2. Jumlah volume sampah yang terangkut ke Tempat Pembuangan Akhir (TPA) sampah masih rendah dibandingkan total produksi sampah yang dihasilkan.

3. Kurangnya pegawai pengangkut sampah.

4. Sudah ada pengelolaan sampah tetapi belum maksimal.

\section{METODE}

Metode yang digunakan dalam penelitian ini adalah pendekatan kualitatif dengan metode analisis deskriptif, yakni sebuah desain yang memberi kemudahan bagi peneliti untuk merekam, memantau, dan mengikuti proses suatu peristiwa atau kegiatan sebuah organisasi sebagaimana adanya dalam suatu kurung waktu tertentu dan selanjutnya diinterprestasikan untuk menjawab masalah penelitian.

Digunakannya metode deskriptif dengan pendekatan kualitatif, dimaksudkan untuk membuat dekripsi, gambaran secara sistematis, faktual, dan akurat mengenai suatu obyek, suatu set kondisi pada masa sekarang serta hubungan antar fenomena yang diselidiki.

Penelitian kualitatif tidak dipersoalkan jumlah informan, tetapi bisa tergantung dari tepat tidaknya pemilihan informan kunci, dan komplesitas dari keragaman fenomena sosial yang diteliti. Dengan demikian, informan ditentukan dengan teknik snowball sampling, yakni proses penentuan informan berdasarkan informan sebelumnya tanpa menentukan jumlahnya secara pasti dengan menggali informasi terkait topik penelitian yang diperlukan.

\section{Informan Penelitian}

Penelitian kualitatif tidak dimaksudkan untuk membuat gambaran generalisasi dari hasil penelitiannya. Oleh karena itu, pada penelitian kualitatif tidak dikenal adanya populasi dan sampel (Bagong Suyanto, 2005 : 171). Subyek penelitian yang telah tercermin dalam fokus penelitian ditentukan secara tidak sengaja. Subyek penelitian ini menjadi informan yang akan memberikan berbagai informasi yang diperlukan selama proses penelitian. Informan adalah seseorang yang benar-benar mengetahui suatu persoalan atau permasalahan tertentu yang darinya dapat diperoleh informasi yang jelas, akurat, dan terpercaya baik berupa pertanyaan, keterangan, atau data-data yang membantu dalam memahami persoalan atau permasalahan tersebut.

Menurut Bagong Suyanto (2005 : 172) informan penelitian meliputi beberapa macam, yaitu :

1. Informan Kunci (Key Informan) merupakan mereka yang mengetahui dan memiliki berbagai informasi pokok yang diperlukan dalam penelitian.

2. Informan Utama merupakan mereka yang terlibat langsung 
dalam interaksi sosial yang diteliti.

Dalam penelitian ini, penulis menggunakan informan kunci dan informan utama, yaitu sebagai berikut

1. Informan Kunci (Key Informan) adalah Kepala Bidang Kebersihan dan Pertamanan Dinas Tata Ruang Permukiman dan Kebersihan Kabupaten Subang. Dipilih karena dipandang sebagai narasumber yang mengetahui tentang kegiatan penanganan dan pengelolaan sampah karena Bidang Kebersihan dan Pertamanan sebagai penyelenggara dan pengendalian kegiatan teknis operasional kebersihan dan pembuangan akhir.

2. Sedangkan Informan Utama adalah :

a. Kepala Operasional Kebersihan. Dipilih karena dipandang sebagai narasumber yang mengetahui tentang kegiatan pengelolaan sampah karena bertugas untuk penyusunan rencana dan program kerja operasional kebersihan dan persampahan.

b. Kepala Seksi Persampahan, karena merupakan pelaksana yang tahu persis permasalahan yang ada di lapangan.

c. Perwakilan Masyarakatyang bertempat tinggal di Kota Subang, karena masyarakat Subang yang telahmerasakan dampak sampah itu.

\section{Instrumen Penelitian}

Instrumen penelitian adalah alat yang dapat digunakan untuk mengumpulkan data penelitian, karena alat atau instrumen ini mencerminkan juga cara pelaksanaannya, maka sering juga disebut dengan teknik penelitian (Wina Sanjaya, 2002 : 86).

Untuk itu instrumen penelitian yang akan digunakan adalah pedoman wawancara (quisioner interview) yang merupakan penuntun bagi peneliti dalam mengembangkan pertanyaanpertanyaan yang bersifat terbuka sehingga memberikan kebebasan yang seluas-luasnya bagi responden untuk menyampaikan pendapatnya.

Pedoman wawancara mendalam di susun menggunakan pertanyaan terbuka, berisi tentang garis-garis besar atau pokok-pokok yang akan ditanyakan sesuai dengan tujuan penelitian. Hasil wawancara direkam menggunakan alat perekam selanjutnya dilakukan untuk pengelompokan data.

\section{Teknik Pengumpulan Data}

Dalam penelitian ini penulis menggunakan dua macam data menurut klasifikasi jenis dan sumbernya, yaitu :

1. Teknik Pengumpulan Data Primer Pengumpulan data primer tentang persampahan dilakukan dengan metode wawancara, yaitu teknik pengumpulan data dengan mengajukan pertanyaan-pertanyaan langsung kepada informan kunci dan informan utama.Penelitian ini melakukan wawancara langsung dengan kepala informan, yaitu informan terkunci dan informan utama.

2. Teknik Pengumpulan Data Sekunder

a. Penelitian kepustakaan, yaitu dengan mengumpulkan data dan informasi melalui literature yang 
relevan dengan judul penelitian seperti buku-buku, artikel, dan makalah yang memiliki relevansi dengan masalah yang diteliti serta analisis peraturan daerah.

b. Studi dokumentasi, yaitu dengan cara memperoleh data melalui pengkajian dan penelaahan terhadap catatan penulis maupun dokumen-dokumen yang berkaitan dengan masalah yang di teliti.

\section{Validitas Data}

Penelitian merupakan sebuah kegiatan yang dilakukan secara ilmiah untuk menemukan jawaban atas permasalahan. Penelitian diartikan sebagai suatu proses pengumpulan dan analisis data yang dilakukan secara sistematis dan logis untuk mencapai tujuan-tujuan tertentu. Salah satu langkah dalam melakukan penelitian adalah dengan mengumpulkan data yang akan dipakai sebagai bahan pengambilan kesimpulan untuk mendapatkan jawaban penelitian. Pengumpulan data dapat dilakukan dengan berbagai metode sesuai dengan tujuan dan karakteristik penelitian.Data yang telah dikumpulkan perlu di cek keabsahannya untuk dikenali validitasnya.Pengecekan data untuk memperoleh keyakinan terhadap kebenaran data pada penelitian kualitatif dapat dilakukan dengan triangulasi.

Triangulasi adalah suatu cara mendapakan data yang benar-benar absah dengan menggunakan pendekatan metode ganda. Triangulasi adalah teknik pemeriksaan keabsahan data dengan cara memanfaatkan sesuatu yang lain di luar data iu sendiri, untuk keperluan pengecekan atau sebagai pembanding terhadap data itu. Triangulasi ada berbagai macam cara, yaitu :

\section{Triangulasi Data}

Triangulasi data berarti membandingkan mengecek ulang derajat kepercayaan suatu informasi yang diperoleh melalui sumber yang berbeda. Misalnya membandingkan antara apa yang dikatakan umum dengan yang dikatakan secara pribadi, membandingkan hasil wawancara dengan dokumen yang ada.

\section{Triangulasi Sumber}

Triangulasi sumber untuk menguji kredibilitas data dilakukan dengan cara mengecek data yang telah diperoleh melalui beberapa sumber. Sebagai contoh, untuk menguji kredibilitas data tentang gaya kepemimpinan seseorang, maka pengumpulan dan pengujian data yang telah diperoleh dilakukan ke bawahan yang dipimpin, ke atasan yang menugasi, dan ke teman kerja yang merupakan kelompok kerjasama. Data dari ketiga sumber tersebut, tidak bisa dirata-ratakan seperti dalam penelitian kuantitatif, tetapi dideskripsikan, dikategorisasikan, mana pandangan yang sama, mana pandangan yang berbeda, dan mana spesifik dari ketiga sumber data tersebut. Data yang telah dianalisis oleh peneliti sehingga menghasilkan suatu kesimpulan selanjutnya dimintakan kesepakatan dengan tiga sumber data tersebut.

\section{Analisis Data}

Analisis data merupakan proses mencari dan mengatur secara sistematis transkrip wawancara, hasil observasi, dokumentasi, dan catatan lapangan serta dengan bahan lain yang dipahami oleh peneliti. Kegiatan analisis data dilakukan dengan menelaah data, menata data, membagi 
menjadi satuan-satuan yang dapat dikelola, mensintesis, mencari pola, menemukan apa yang bermakna dan apa yang diteliti dan dilaporkan secara sistematis.

Data itu sendiri terdiri dari deskripsi-deskripsi yang rinci mengenai situasi, peristiwa, orang, interaksi, dan perilaku. Dengan kata lain data merupakan deskripsi dari pertanyaan-pertanyaan seseorang tentang perspektif pengalaman suatu hal, sikap, keyakinan, dan pikirannya serta petikan-petikan isi dokumen yang berkaitan dengan suatu program.

Analisis data dilakukan selama pengumpulan data tentang persampahan di lapangan terkumpul (Sudarsono, 2003 : 326), dengan teknik analisis model interaktif yang dikembangkan oleh Miles and Huberman. Dalam model Miler and Huberman analisis data berlangsung secara stimulan yang dilakukan bersamaan dengan proses pengumpulan data dengan alur tahapan : pengumpulan data (data collection), reduksi data (data reduction), penyajian data (data display), dan kesimpulan atau verifikasi (conclution drawing \& berififying) teknik analisis data model interaktif tersebut dapat dibagankan sebagai berikut.

Penelitian menggunakan model analisis interaktif yang mencakup tiga komponen yang saling berkaitan, yaitu reduksi data, penyajian data, dan penarikan kesimpulan. Sedangkan konseptualisasi, kategorisasi, dan deskripsi dikembangkan atas dasar kejadian (incidence) yang diperoleh keika di lapangan.Karenanya antara kegiatan pengumpulan data dan analisis data menjadi satu kesatuan yang tidak mungkin dipisahkan, keduanya berlangsung stimulant dan serempak. Proses analisis data disini terbagi menjadi empat komponen, antara lain sebagai berikut :

1. Pengumpulan Data

Data-data yang diperoleh di lapangan dicatat atau direkam dalam bentuk naratif, yaitu uraian data yang diperoleh dari lapangan apa adanya tanpa komentar peneliti berbentuk catatan kecil. Dari catatan deskriptif ini, kemudian dibuat catatan refleksi, yaitu catatan yang berisi komentar, pendapat/penafsiran peneliti atau fenomena yang ditemui di lapangan.

2. Reduksi Data

Reduksi data merupakan suatu bentuk analisis yang menajamkan, menggolongkan, mengarahkan, membuang yang tidak perlu, dan mengoranisasikan data sedemikian rupa sehingga diperoleh kesimpulan akhir dan diverifikasi. Reduksi data juga diartikan sebagai proses pemilihan, pemusatan perhatian pada penyederhanaan, dan transformasi data kasar yang muncul dari catatancatatan tertulis di lapangan. Reduksi data berlangsung terus menerus selama penelitian berlangsung, bahkan sebelum data benar-benar terkumpul, sudah mengantisipasi adanya reduksi data sudah tampak sewaktu memutuskan kerangka konseptual, wilayah penelitian, permasalahan penelitian, dan penentuan metode pengumpulan data. Pengumpulan data berlangsung sudah ada tahapan reduksi, selanjutnya membuat ringkasan, mengkode, menelusuri tema, dan menulis memo. Proses ini belanjut sampai proses pengumpulan data di lapangan berakhir, bahkan 
pada saat pembuatan laporan sehingga tersusun secara lengkap. Data yang telah diperoleh di sederhanakan dan di seleksi relevansinya dengan masalah penelitian, sedangkan data yang tidak diperlukan dibuang.

3. Penyajian Data

Sebagaimana dijelaskan oleh Huberman dalam (Meleong, 2005 : 44) bahwa penyajian data dimaksudkan untuk menemukan pola-pola yang bermakna serta memberikan kemungkinan adanya penarikan kesimpulan dan pengambilan tindakan. Penyajian data dalam penelitian ini juga dimaksudkan untuk menemukan suatu makna dari data-data yang sudah diperoleh, kemudian disusun secara sistematis dari bentuk informasi yang kompleks menjadi sederhana namun selektif.

4. Verifikasi (menarik Kesimpulan)

Kegiatan analisis data pada tahap terakhir adalah menarik kesimpulan dan verifikasi.Analisis yang dilakukan selama pengumpulan data dan sesudah pengumpulan data digunakan untuk menarik kesimpulan sehingga menemukan pola tentang peristiwa-peristiwa yang terjadi.Sejak pengumpulan data peneliti berusaha mencari makna atau arti dari simbolsimbol, mencari keteraturan pola, penjelasan-penjelasan, dan alur sebab akibat yang terjadi.Dari kegiatan ini dibuat kesimpulan-kesimpulan yang difatnya masih terbuka, kemudian menuju ke yang spesifik/rinci. Kesimpulan terakhir diharapkan dapat diperoleh setelah pengumpulan data selesai (Meleong, 2005 : 44).

HASIL DAN PEMBAHASAN

\section{Kinerja Bidang Kebersihan dan Pertamanan Dinas Tata Ruang,Permukiman dan Kebersihan Dalam Menangani Sampah di Kabupaten Subang}

Permasalahan lingkungan
yang umum terjadi di perkotaan adalah pengelolaan sampah perkotaan yang kurang baik.Sampah yang merupakan bagian sisa aktifitas manusia perlu dikelola dengan baik agar tidak menimbulkan berbagai permasalahan terhadap kehidupan manusia maupun gangguan pada lingkungan seperti pencemaran lingkungan, penyebaran penyakit, menurunnya estetika dan sebagai pembawa penyakit.Pengelolaan sampah di kota-kota di Indonesia sampai saat ini belum mencapai hasil yang optimal.Berbagai kendala masih dihadapi dalam melaksanakan pengelolaan sampah tersebut baik kendala ekonomi, sosial budaya maupun penerapan teknologi.

Permasalahan pengelolaan persampahan menjadi sangat serius di perkotaan akibat kompleksnya permasalahan yang dihadapi dan kepadatan penduduk yang tinggi, sehingga pengelolaan persampahan sering diprioritaskan penanganannya di daerah perkotaan. Permasalahan dalam pengelolaan sampah yang sering terjadi antara lain perilaku dan pola hidup masyarakat masih cenderung mengarah pada peningkatan laju timbulan sampah yang sangat membebani pengelola kebersihan, keterbatasan sumber daya, anggaran, kendaraan personil sehingga pengelola kebersihan belum mampu melayani seluruh sampah yang dihasilkan. 
Sejalan dengan itu, pelayanan pengelolaan sampah termasuk dalam pelayanan publik yang bertujuan untuk melayani masyarakat dalam pengelolaan sampah yang dihasilkan.Dalam pelayanan pengelolaan sampah sangat dibutuhkan kinerja atau performance yang baik sehingga pengelolaan sampah dapat berjalan efektif dan efisien serta dapat memberikan kepuasan kepada masyarakat sebagai pelanggan.

Namun demikian, seringkali terjadi penanganan sampah perkotaan menjadi tidak efektif akibat keterbatasan Pemerintah baik dalam pembiayaan, jumlah personil maupun jumlah peralatan yang tersedia.Kabupaten Subang merupakan wilayah perkotaan yang merupakan contoh nyata dalam hal persoalan sampah.Beberapa titik di Kabupaten Subang telah membuktikan bahwa fenomena sampah sukar untuk dihilangkan. Dengan jumlah penduduk di Kabupaten Subang pada tahun 2014 mencapai 1.677.790 jiwa dengan kepadatan penduduk 8,18 jiwa/ha. Jumlah penduduk Kabupaten Subang yang banyak dengan peningkatan pertumbuhan yang tinggi mengakibatkan bertambahnya volume sampah.Dengan pola konsumsi masyarakat yang berbedabeda maka beragam jenis sampah pula yang ditimbulkan.

Selain itu faktor yang mempengaruhi sampah baik kualitas amupun kuantitas sangat dipengaruhi oleh berbagai kegiatan dari taraf hidup manusia. Beberapa faktor penting yang mempengaruhi jumlah sampah antara lain :
1. Jumlah penduduk, dapat dipahami dengan mudah bahwa semakin banyak penduduk semakin banyak pula sampah yang diproduksi. Pengelolaan sampah ini berpacu dengan lajur pertumbuhan jumlah penduduk.

2. Keadaan sosial dan ekonomi, semakin tinggi keadaan sosial ekonomi masyarakat maka semakin banyak pula sampah yang dibuang.

3. Kemajuan teknologi, kemampuan teknologi akan menambah jumlah ataupun kualitas sampah, karena pemakaian bahan baku yang sangat berguna.

Dalam pengelolaan sampah di Kabupaten Subang bukan hanya tanggung jawab Bidang Kebersihan dan Pertamanan saja, akan tetapi setiap masyarakat juga diwajibkan untuk bertanggung jawab terhadap lingkungannya atau sampah yang dihasilkan.

Kinerja Bidang Kebersihan dan Pertamanan dalam penanganan sampah yang baik sangat berpengaruh terhadap pelayanan publik yang mengutamakan kepuasan masyarakat atas pengelolaan sampah di Kabupaten Subang.Bidang Kebersihan dan Pertamanan merupakan pelaksana pemerintahan dan pelayanan kepada masyarakat.Bidang Kebersihan dan Pertamanan mempunyai peran yang sangat penting dalam sistem pemerintahan karena di sini Bidang Kebersihan dan Pertamanan berhubungan langsung dengan masyarakat.Kinerja dalam organisasi publik pun harus tercipta dengan baik agar dalam penyelenggaraan dapat berjalan efekif dalam melayani masyarakat. 
Bidang Kebersihan dan Pertamanan dalam pengelolaan sampah adalah kegiatan sistematis, menyeluruh dan berkesinambungan yang meliputi pengurangan dan penanganan sampah.Pengelolaan sampahnya di mulai dari pengumpulan, pengangkutan hingga pembuangan akhir sampah ke tempat pembuangan akhir.Dalam pengumpulan sampah dari TPS ke TPA digunakan pengangkut truk.

Dalam pengelolaan sampah, dampah yang telah terkumpul dapat diolah lebih lanju, baik dilokasi sumber sampah maupun setelah sampai di TPA. Tujuannya agar sampah dapat dimanfaatkan kembali, sehingga dapat mengurangi tumpukan sampah serta memperoleh nilai ekonomi dari sampah

\section{Dimensi Produktivitas}

Dwiyanto (2006 :50-51) mengemukakan bahwa konsep produktivitas tidak hanya mengukur tingkat efisiensi, tetapi juga efektivitas pelayanan. Produktivitas pada umumnya dipahami sebagai rasio antara input dan output yang dapat diartikan sejauh mana perbandingan antara upaya yang dilakukan dengan hasil yang diperoleh. Produktivitas secara konseptual adalah hubungan antara keluaran atau hasil organisasi dengan masukan yang diperlukan. Menaikan produktivitas dapat dilakukan dengan memperbaiki rasio produktivitas, dengan menghasilkan lebih banyak keluaran atau output yang lebih baik dengan tingkat masukan sumber daya tertentu.

Suatu organisasi dikatakan produktif apabila mencapai tujuannya dan hal itu terjadi dengan mengubah masukan menjadi keluaran dengan biaya rendah.Dalam penelitian ini produktivitas di Bidang Kebersihan dan Pertamanan dalam menangani sampah di Kabupaten Subang meliputi pelayanan yang dikeluarkan oleh Bidang Kebersihan dan Pertamanan memiliki hasil yang diharapkan sebagai salah satu indikator yang penting.

Berdasarkan penjelasan di atas mengenai konsep produktivitas maka dalam penelitian ini akan menekankan konsep produktivitas pada sejauh mana upaya yang telah dilakukan oleh Bidang Kebersihan dan Pertamanan Dinas Tata Ruang Permukiman dan Kebersihan dalam menangani sampah di Kabupaten Subang. Hal ini dapat diketahui dengan berbagai kegiatan apa saja yang dilakukan dalam upaya penanganan sampah di Kabupaten Subang dan apakah hasilnya sesuai dengan target yang telah ditetapkan.

Dalam menjalankan tugasnya

Bidang Kebersihan dan Pertamanan mempunyai tujuan sebagai berikut sebagai penyelenggara dan pengendali kegiatan teknis operasional kebersihan, penyelenggara dan pengendali kegiatan teknis operasional pembuangan akhir, penyelenggara pembinaan di bidang kebersihan dan pertamanan dan sebagai penyelenggara kegiatan penanganan kegiatan persampahan. Seperti yang dikatakan oleh Kepala Bidang Kebersihan dan Pertamanan sebagai berikut: " Tujuannya yang pertama, Bidang Kebersihan dan Pertamanan sebagai unsur pelaksana Pemerintah Daerah di Bidang Kebersihan dan Pertamanan. Kita ingin melayani masyarakat secara baik, berkualitas 
dan disini dari awal kita sudah berkomitmen, pelayanan yang diberikan kepada masyarakat bidang kebersihan dan pertamanan harus menyelesaikan tugas dengan baik." (Hasil Wawancara, September 2016)

Dari hasil penuturan Kepala Bidang Kebersihan dan Pertamanan dapat disimpulkan bahwa Bidang Kebersihan dan Pertamanan mempunyai tujuan untuk melayani masyarakat dengan baik dan berkualitas. Pelayanan yang diberikan oleh Bidang Kebersihan dan Pertamanan juga cepat, sehingga menjadikan wilayah Kabupaten Subang lebih bersih dengan adanya pelayanan yang berkualitas, maka banyak masyarakat merasa puas dengan pelayanan yang diberikan.

Pelayanan penanganan sampah yang diberikan oleh Bidang Kebersihan dan Pertamanan Kabupaten Subang termasuk dalam pelayanan publik yang bertujuan untuk melayani masyarakat dalam penanganan sampah yang dihasilkan.Dalam pelayanan penanganan sampah sangat dibutuhkan kinerja atau performanceyang baik sehingga penanganan sampah dapat berjalan efektif dan efisien serta dapat memberikan kepuasan kepada masyarakat sebagai pelanggan.

Namun demikian, seringkali terjadi penanganan sampah menjadi tidak efektif akibat keterbatasan Pemerintah baik dalam pembiayaan, jumlah personil maupun jumlah peralatan yang tersedia.

Dalam penanganan sampah di Kabupaten Subang Bidang Kebersihan dan Pertamanan dalam pengangkutannya harus sesuai dengan standar yang telah ditentukan. Seperti yang diungkapkan oleh Kasie Operasional dan Kasie Persampahan Bidang Kebersihan dan Pertamanan sebagai berikut : "Dalam melaksanakan tugasnya petugas kebersihan sudah sesuai dengan baik dalam menyelesaikan tugas yang diberikan dalam pengangkutan sampah.Tugas pengangkutan sampah yang diberikan kepada petugas memang hanya 1 kali pengangkutan di setiap TPS karena keterbatasan armada yang ada." (Hasil Wawancara, September 2016)

Memang karena keterbatasan armada yang dimiliki oleh Bidang Kebersihan dan Pertamanan menjadi kendala dalam pengelolaan kebersihan di Kabupaten Subang. Menurut SK SNI T-13-1990-F, pada dasarnya sistem pengelolaan sampah perkotaan dilihat sebagai komponenkomponen subsistem yang saling mendukung, saling berinteraksi, dan saling berhubungan satu sama lain, seperti gambar Skema Sistem Pengelolaan Sampah. 


\section{SKEMA SISTEM PENGELOLAAN SAMPAH PERKOTAAN}

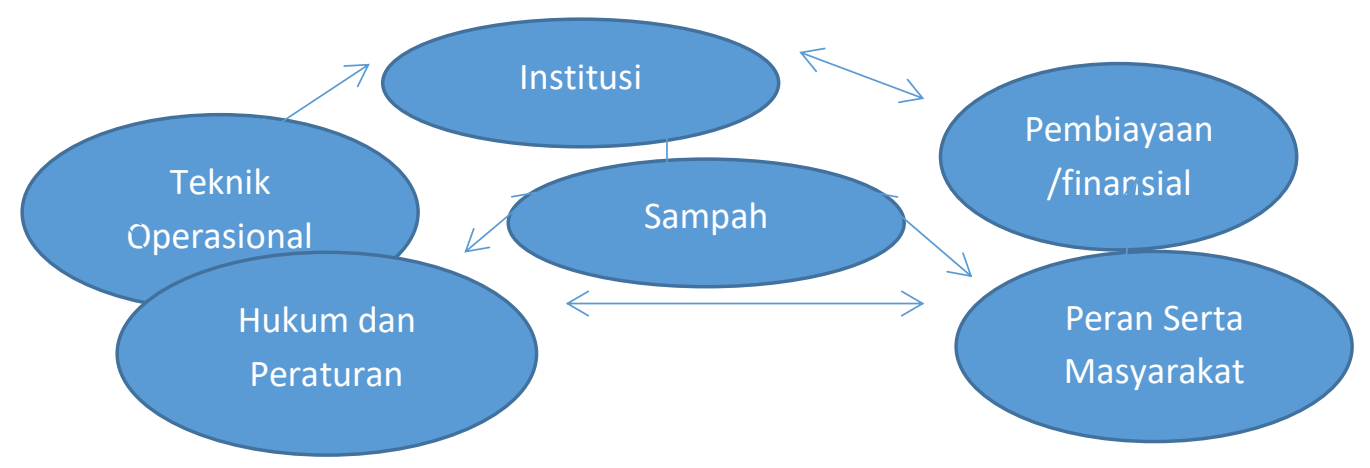

Sumber : SK SNI T-13-1990-F

Pola pengangkutan sampah yang tidak efektif juga akan mempengaruhi jangkauan layanan maupun biaya operasional pengangkutan. Karena keterbatasan pemerintah dalam pengelolaan sampah tersebut maka perlu didukung adanya peran serta masyarakat dalam pengelolaan sampah baik peran serta aktif maupun pasif. Peran serta masyarakat sangat dibutuhkan dalam hal pengelolaan sampah karena pengelolaan sampah adalah tanggung jawab kita bersama kesadaran masyarakat akan lingkungan bersih akan membuat hidup kita hidup sehat. Untuk peningkatan penanganan persampahan banyak hal yang harus ditinjau diantaranya operasional pengumpulan, pengangkutan, dan pembuangan akhir serta peralatan yang digunakan.Disamping itu yang sangat berperan adalah aspek organisasi dan manajemen di dalam pengelolaannya.Seperti yang diungkapkan salah seorang warga Kelurahan Pasirkareumbi. "Kalau menurut penilaian saya, Bidang Kebersihan sudah cukup tanggap dalam memenuhi pelayanan kebersihan kepada
masyarakat.Dilihat dari pengangkutan sampah yang dilakukan dalam 1 kali dalam seminggu memang sebenarnya itu masih terasa kurang yang seharusnya minimal 2 kali dalam seminggu." (Hasil Wawancara, September2016)

Berdasarkan hasil wawancara diatas, maka masyarakat sudah merasa puas atas pelayanan yang diberikan oleh Bidang Kebersihan dan Pertamanan dalam pengelolaan kebersihan.Walaupun belum optimal karena masih kurangnya pengangkutan sampah ke setiap warga di Kabupaten Subang.Memang seharusnya frekuensi pengangkutan perlu ditetapkan dengan teratur, disamping untuk memberikan gambaran kualitas pelayanan, juga untuk menetapkan jumlah kebutuhan tenaga dan peralatan, sehingga biaya operasi dapat diperkirakan.

Penetapan target bagi organisasi merupakan sarana untuk memacu organisasi tersebut dalam mencapai tujuannya. Masalah yang lebih sulit lagi adalah bagaimana pencapaian target tersebut, karena untuk mencapai target itu dipengaruhi beberapa faktor, yaitu sarana dan prasarana harus memadai, biaya 
operasional tercukupi sehingga daya dukung pencapaian penanganan sampah dapat diatasi dengan baik.

Dapat disimpulkan bahwa produktivitas Bidang Kebersihan dan Pertamanan dalam penanganan sampah di Kabupaten Subangcukup baik.Dilihat dari sistem pengangkutan yang dilihat sudah mulai rutin dilakukan walaupun masih adanya volume sampah yang tidak terangkut karena keterbatasan prasarana.Maka produktivitas Bidang Kebersihan dan Pertamanan perlu ditingkatkan lagi dalam memberikan pelayanan penanganan sampah terhadap masyarakat.

\section{Kualitas Layanan}

Dwiyanto (2006 :50-51)
mengemukakan bahwa isu itu mengenai kualitas layanan cenderung menjadi penting dalam menjalankan kinerja organisasi publik.Hal ini disebabkan adanya pandangan negatif yang terbentuk mengenai organisasi public muncul karena ketidakpuasan masyarakat terhadap kualitas layanan yang diterima.Kinerja pelayanan juga dapat dilihat dari kualitas layanan yang diberikan organisasi publik terhadap masyarakat.Karena sekarang ini, kualitas pelayanan menjadi cenderung penting dalam menjelaskan kinerja organisasi pelayanan publik.Banyak terjadi kasus ketidakpuasan terhadap kualitas layanan dari suatu organisasi publik.Maka dari itu, kepuasan masyarakat terhadap layanan yang didapat, dapat dijadikan indikator kinerja organisasi publik.Penggunaan kepuasan masyarakat menjadi keuntungan karena informasi tentang kepuasan masyarakat seringkali tersedia secara mudah dan murah.
Seperti yang telah dijelaskan, bahwa kinerja organisasi publik juga dapat dilihat dari kualitas pelayanan yang diberikan organisasi publik tersebut kepada masyarakat.Kualitas pelayanan Bidang Kebersihan dan Pertamanan adalah bagaimana dalam memberikan pelayanan kepada masyarakat dalam hal pengelolaan sampah di Kabupaten Subang.

Pelayanan yang diberikan oleh Bidang Kebersihan dan Pertamanan dalam proses pengelolaan sampah adalah sebagai berikut :

1. Penampungan (Pewadahan)

Dalam pola penampungan ada 2 macam, yaitu :

a. Individual yaitu rumah atau took dan bangunan lainnya yang memiliki wadah sendiri, kemudian sampah yang dari pewadahan dikumpulkan oleh petugas kebersihan dengan menggunakan gerobak sampah, sampah dipindahkan ke TPS.

b. Komunal yaitu tipe komunal ini sangat tepat untuk daerah permukiman yang berpenghasilan rendah atau daerah permukiman padat tidak teratur yang kondisi jalannya tidak dapat dilihat dilalui oleh alat pengumpul.

2. Pengumpulan

Sebagai pengelola sampah dari tempat sumbernya sampai ketempat TPS sebelum menuju ke tahapan berikutnya.

3. Pemindahan

Pemindahan sampah dari alat pengumpul ke alat angkut dilakukan transfer depo atau tempat pembuangan sementara.

4. Pengangkutan 
Dalam pelayanan pengangkutan sampah menggunakan sarana berupa alat transportasi seperti dump truck atau arm roll.Untuk mengangkut sampah sampai ke TPA atau pengolahan.

5. TPA (Tempat Pembuangan Akhir)

Tingkat upaya pemusnahan yang akhir dari adanya sampah, apakah sampah dan tempat-tempat umum, pemukiman, pasar, pertokoan, industry, maupun sampah hasil dari penyapuan jalan yang dikumpulkan dan diangkat secara langsung ke tempat pembuangan akhir.

Dalam pelaksanaannya

Bidang Kebersihan dan Pertamanan dalam penanganan sampah harus sesuai dengan standar operasional prosedur yang telah ditentukan. Seperti wawancara yang dilakukan kepada Kepala Bidang Kebersihan dan Pertamanan, sebagai berikut : "Dalam setiap melakukan tugasnya Bidang Kebersihan dan Pertamanan selalu memperhatikan SOP yang telah ditentukan.Karena SOP sebagai pijakan kami dalam penanganan kebersihan.Bidang Kebersihan dan Pertamanan membuat petunjuk teknis dalam penanganan kebersihan". (Hasil Wawancara, September 2016)

Ketersedian sarana dan prasarana yang baik, akan mempengaruhi persepsi masyarakat terhadap kualitas pelayanan. Sarana dan prasarana tersebut sebagai contoh seperti armada angkutan sampah, tong sampah, tersedianya tempat pembuangan sementara dan lainlain.Berikut gambar sarana dan prasarana yang dimiliki Bidang Kebersihan dan Pertamanan terhadap masyarakat. Berikut penuturan Kasie
Operasional dan Kasie Persampahan Bidang Kebersihan dan Pertamanan, sebagai berikut : "Pelayanan terhadap kebutuhan masyarakat masih belum maksimal karena kurang tersedianya sarana dan prasarana serta belum optimalnya biaya operasional yang dimiliki oleh Bidang Kebersihan dan Pertamanan.Sehingga pelayanan kepada masyarakat menjadi kurang". (Hasil Wawancara, September 2016)

Berdasarkan hasil wawancara diatas, salah satu bentuk kualitas pelayanan adalah mengenai sarana dan prasarana yang ada di Bidang Kebersihan dan Pertamanan menyangkut pada pemberian pelayanan kepada masyarakat.Sebagai penyedia pelayanan, harus selalu memperhatikan sarana dan prasarana untuk suatu kegiatan pelayanan kepada masyarakat dalam penanganan sampah di Kabupaten Subang. Berdasarkan hasil wawancara dengan salah seorang warga ternyata kualitas pelayanan pengangkutan sampah yang diberikan masih dirasakan kurang.Dan juga kurang terawatnya TPS menjadi kendala masyarakat yang malas dalam membuang sampah di TPS.Seharusnya sarana yang ada dirawat dengan baik oleh semua Seharusnya dengan adanya sarana dan prasarana yang ada kebersihan harus lebih mengoptimalkan terhadap penanganan sampah dapat berjalan efektif dan efisien serta dapat memberikan kepuasan kepada masyarakat.Namun demikian, seringkali terjadi penanganan sampah menjadi tidak efektif akibat keterbatasan Pemerintah baik dalam pembiayaan, jumlah personil maupun jumlah peralatan yang tersedia. 
Sumber daya manusia juga merupakan faktor pendorong keberhasilan dari sebuah organisai, karena keberhasilan suatu organisasi tergantung dari kemampuan sumber daya manusia yang dimiliki.

Kualitas pelayanan sebenarnya dapat dikatakan tergantung pada kemampuan pegawai dalam memberikan pelayanan kepada masyarakat. Demi terciptanya pelayanan yang berkualitas, maka dibutuhkan kemampuan kehandalan para pegawai dalam memberikan pelayanan kepada masyarakat dalam penanganan sampah.

Kualitas layanan merupakan hal yang penting dalam penanganan sampah di Kabupaten Subang.Karena baik dan buruknya pelayanan sampah di Kabupaten Subang tergantung bagaimana kualitas layanan yang diberikan Bidang Kebersihan dan Pertamanan kepada masyarakat.

Dapat disimpulkan kualitas layanan yang diberikan oleh Bidang Kebersihan dan Pertamanan kurang baik.Dilihat dari kendalanya adalah pendanaan/anggaran yang masih kurang, kurangnya jumlah personil pengangkutan sampah, kurangnya sarana dan prasarana yang dimiliki sehingga kinerja bidang kebersihan dan pertamanan dalam penanganan sampah menjadi terganggu.

\section{Responsivitas}

Dwiyanto (2006 :50-51) mengemukakan bahwa Responsivitas adalah kemampuan organisasi untuk mengenali kebutuhan masyarakat, menyusun agenda dan prioritas pelayanan dan mengembangkan program-program pelayanan publik sesuai dengan kebutuhan dan aspirasi masyarakat. Responsivitas dimasukkan sebagai salah satu indikator kinerja karena responsivitas secara langsung menggambarkan kemampuan organisasi publik dalam menjalankan misi dan tujuannya, terutama untuk memenuhi kebutuhan masyarakat.

Responsivitas menurut Dwiyanto (2006 :50-51) dalam operasionalisasinya dijabarkan menjadi beberapa indikator yaitu :

a. Terdapat tidaknya keluhan pengguna jasa selama satu tahun terakhir ;

b. Sikap aparat birokrasi dalam merespon keluhan dari pengguna jasa ;

c. Penggunaan keluhan dari pengguna jasa sebagai referensi bagi perbaikan penyeenggaraan pelayanan pada masa mendatang ;

d. Berbagai tindakan aparat birokrasi untuk memberikan kepuasan pelayanan pada pengguna jasa ;

e. Penempatan pengguna jasa oleh aparat birokrasi dalam sistem pelayanan yang berlaku.

Responsivitas disini menunjukkan pada keselarasan antara program dan kegiatan pelayanan dengan kebutuhan dan aspirasi masyarakat.Responsivitas secara tidak langsung menggambarkan kemampuan organisasi publik dalam menjalankan misi dan tujuannya terutama untuk memenuhi kebutuhan masyarakat.

Responsivitas yang rendah menunjukkan kegagalan organisasi dalam mewujudkan misi dan tujuan organisasi publik.Organisasi yang memiliki responsivitas yang rendah dengan sendirinya memiliki kinerja yang buruk. Sebuah organisasi publik 
harus mempunyai reponsivitas yang tinggi terhadap apa yang menjadi permasalahan, kebutuhan, keluhan dan aspirasi masyarakat.

Organisasi hendaknya cepat memahami apa yang menjadi tuntutan masyarakat dan berusaha semaksimal mungkin memenuhinya. Organisasi dapat menangkap masalah yang dihadapi publik dan berusaha untuk mencapai solusinya.Sehingga dengan demikian dibutuhkan sumber daya manusia yang memadai dan peka agar dapat lebih mengenali aspirasi masyarakat serta dapat memberikan solusi terhadap tuntutan kebutuhan masyarakat.

Sikap responsif dari Bidang Kebersihan dan Pertamanan dapat dilihat dari bagaimana Bidang Kebersihan dan Pertamanan dalam memberikan dan menyediakan sarana pelayanan serta kesigapan dalam memberikan pelayanan kepada masyarakat.Kebutuhan disini mencakup segala sarana yang dibutuhkan pegawai Bidang Kebersihan dan Pertamanan untuk melayani pelanggan. Untuk itu Bidang Kebersihan dan Pertamanan dituntut untuk mempunyai fasilitas yang memadai yanga akan menciptakan pelayanan yang berkualitas.

Sikap responsif dari Bidang Kebersihan dan Pertamanan dapat dilihat dari hasil wawancara dengan Kepala Bidang Kebersihan dan Pertamanan berikut ini : "Kita adalah lembaga pelayanan publik yang selalu berusaha untuk memberikan pelayanan terbaik.Kita juga menerapkan prosedur pelayanan penanganan sampah itu harus sesuai dengan tupoksi.Sehingga diharapkan pelayanan yang kami berikan itu berusaha untuk memenuhi tuntutan atau kebutuhan masyarakat." (Hasil Wawancara, September 2016)

Sikap responsif diterapkan pada saat penanganan sampah juga harus sesuai dengan tupoksi yang ada.Karena dalam memberikan pelayanan sampah dalam memenuhi kebutuhan masyarakat Bidang Kebersihan dan Pertamanan harus mengetahui kebutuhan masyarakat dan prioritas pelayanan.

Dalam penanganansampah bukan hanya pegawai kebersihan saja yang harus bertanggung jawab tetapi peran serta masyarakat sangat penting dibutuhkan dalam meningkatkan kebersihan di lingkungannya. Dengan responnya pegawai dari Bidang Kebersihan dan Pertamanan dalam penanganan sampah maka diharapkan akan mengurangi keluhan masyarakat seperti, waktu pengangkutan sampah yang tidak tepat pada waktunya.

Sementara itu Kasie Operasional dan Kasie Persampahan Bidang Kebersihan dan Pertamanan juga mengemukakan hal sebagai berikut: "Sikap responsif kita dalam menanggapi kebutuhan masyarakat sudah bagus.Sistem kerja kita juga menuntut agar pegawai harus lebih responsif.Kita juga selalu memberikan pelayanan penanganan sampah kepada masyarakat.Tetapi terkadang dalam menanggapi keluhan masyarakat kita langsung ditindak lanjuti dengan mengerahkan petugas". (Hasil Wawancara, September 2016)

Berdasarkan hasil wawancara di atas menunjukkan bahwa Bidang Kebersihan dan Pertamanan dalam penanganan sampah sudah cukup tanggap dalam memenuhi kebutuhan pelayanan.Hal ini dapat terlihat dari 
banyaknya keluhan-keluhan dari masyarakat dapat pelayanan dengan baik.Dan dapat menyikapi keluhankeluhan dari masyarakat.

Sementara itu, tanggapan dari Ibu yamti warga Kelurahan Karanganyar tentang keluhan kepada Bidang Kebersihan dan Pertamanan dalam Penanganan sampah sebagai berikut : "Saya pernah menyampaikan keluhan kepada Bidang Kebersihan dan Pertamanan dalam penanganan sampah mengenai sistem pengangkutan TPS di dekat rumah saya tentang kurang responnya pegawai dalam mengangkut sampah padahal TPS tersebut terletak di dekat pemukiman sehingga menimbulkan bau.Memang mau mendengarkan keluhan saya dengan baik, namun tidak langsung direalisasikan." (Hasil Wawancara, September 2016)

Berdasarkan hasil wawancara di atas bahwa responsivitas pegawai dalam penanganan sampah masih banyak keluhan yang disampaikan oleh masyarakat.Maka dari itu kinerja Bidang Kebersihan dan Pertamanan dalam penanganan sampah harus lebih ditingkatkan seperti pengangkutan yang rutin di setiap TPSnya sehingga timbulan sampah tidak terlalu banyak dan menimbulkan bau yang tidak sedap.

Konsep responsivitas juga mengarah pada pertanggung jawaban organisasi publik dalam memberikan pelayanan kepada masyarakat.Respon yang diharapkan dari pengguna pelayanan penanganan sampah adalah daya tanggap Bidang Kebersihan dan Pertamanan dalam melayani dan memenuhi kebutuhan masyarakat dengan cepat dan tanpa prosedur yang berbelit-belit serta tepat waktu.

Dapat disimpulkan bahwa responsivitas petugas kebersihan pada Bidang Kebersihan dan Pertamanan dalam penanganan sampah cukup baik.Dilihat dari keluhan yang disampaikan oleh masyarakat kepada pegawai Bidang Kebersihan dan Pertamanan dalam pengangkutan sampah tidak cepat tanggap dalam penanganan sampah tersebut, sedangkan banyak timbunan sampah yang menumpuk dibiarkan terlalu lama sehingga menganggu kenyamanan masyarakat.Maka seharusnya pegawai Bidang Kebersihan dan Pertamanan juga harus lebih memperhatikan lagi keluhan yang disampaikan masyarakat itu dan agar lebih meningkatkan upaya-upaya penanganan sampah lebih cepat agar masyarakat puas dengan pelayanan yang diberikan.

\section{Responsibilitas}

Dwiyanto (2006 :50-51) mengemukakan bahwa reponsibilitas menjelaskan apakah pelaksanaan kegiatan organisasi publik itu dilakukan sesuai dengan prinsipprinsip administrasi yang benar atau sesuai dengan pembinaan penanganan sampah. Responsibilitas berhubungan dengan sejauh mana instansi pemerintah melaksanakan segala kegiatannya sesuai dengan prinsip-prinsip dan peraturan yang benar dengan standar profesional dan kompetensi teknis yang dimiliki dalam rangka pencapaian tujuan yang optimal.

$\begin{array}{lr}\text { Dalam } & \text { memberikan } \\ \text { pelayanan kepada } & \text { masyarakat, } \\ \text { Bidang Kebersihan dan Pertamanan }\end{array}$


selalu berdasarkan prosedur yang sudah ada, yaitu tertuang dalam SOP (Standart Operatin Prosedure), sehingga dalam memberikan pelayanan tidak terjadi penyimpangan.

Dalam memberikan pelayanan tentu saja Bidang Kebersihan dan Pertamanan selalu melaui prosedur tersebut. Seperti ungkapan Kasie Operasional Bidang Kebersihan dan Pertamanan sebagai berikut : "Kita ya selalu melalui prosedur yang sudah tertuang di SOP, dalam memberikan pelayanan kepada masyarakat terutama dalam pengangkutan sampah." (Hasil Wawancara, September 2016)

Berdasarkan wawancara di atas, Bidang Kebersihan dan Pertamanan selalu menaati prosedur dalam memberikan pelayanan kepada masyarakat seperti yang sudah ada dalam SOP, sehingga pelayanan yang diberikan dapat tetap berkualitas. Kemampuan Bidang Kebersihan dan Pertamanan dalam penanganan sampah melaksanakan tugas dan tanggung jawabnya sudah dapat dikatakan baik seperti ungkapan dari Kepala Bidang Kebersihan dan Pertamanan sebagai berikut : "Kemampuan Bidang Kebersihan dan Pertamanan sudah bagus.Kemampuan tersebut juga tidak pernah berhenti untuk dikembangkan. Karena kita selalu memberikan kesempatan kepada karyawan dari semua level baik level staf maupun level kepala bagian untuk memperoleh wawasan dan ilmu pengetahuan dalam artian dalam rencana kerja juga dianggarkan biaya pendidikan." (Hasil Wawancara, September 2016)
Ungkapan di atas menunjukkan bahwa Bidang Kebersihan dan Pertamanan selalu memperhatikan kemampuan pegawainya.Biaya pendidikan untuk meningkatkan kemampuan pegawainya pun dianggarkan dalam rencana kerja.Sehingga semua pegawai Bidang Kebersihan dan Pertamanan mempunyai kemampuan baik dalam melaksanakan tugas dan tanggung jawabnya.

Seperti yang telah dijelaskan bahwa responsibilitas dari Bidang Kebersihan dan Pertamanan dalam melaksanakan tugas dan tanggung jawabnya harus sesuai dengan standar professional dan kompetensi aparatur pemerintah dengan mebgarahkan sumber daya yang dimiliki untuk mencapai tujuan yang ditetapkan.

Berdasarkan penjelaskan di atas maka dapat disimpulkan bahwa responsibilitas Bidang Kebersihan dan Pertamanan dalam penanganan sampah sudah baik karena semua kegiatan yang dilakukan di Bidang Kebersihan dan Pertamanan dalam penanganan sampah sudah sesuai dengan standar operasional prosedur yang ada di Bidang Kebersihan dan Pertamanan.

\section{Akuntabilitas}

Dwiyanto (2006 :50-51) mengemukakan bahwa akuntabilitas publik menunjuk pada seberapa besar penanganan sampah dan kegiatan organisasi publik tunduk pada para pejabat politik yang dipilih oleh rakyat. Akuntabilitas dalam penyelenggaraan pelayanan publik adalah suatu ukuran yang menunjukkan seberapa besar kesesuaian penyelenggaraan pelayanan dengan petunjuk pelaksana 
yang menjadi dasar atau pedoman penyelenggaraan pelayanan kepada pihak yang memiliki kewenangan untuk meminta pertanggung jawaban tersebut.

Sesuai dalam undang-undang pihak yang bertanggungjawab dalam penanganan sampah meningkatkan kesehatan masyarakat dan kualitas lingkungan serta menjadikan sampah menjadi sumber daya maka dalam penanganan sampah harus sesuai dengan standar yang telah di tentukan agar penanganan sampah berjalan dengan efektif.

Pertanggungjawaban dari Bidang Kebersihan dan Pertamanan dapat diungkapkan dari hasil wawancara Kepala Bidang Kebersihan dan Pertamanan sebagai berikut : "Yang jelas adalah pertanggungjawaban kepada pemerintahan daerah tentang penanganan sampah dilakukan oleh Bidang Kebersihan dan Pertamanan dengan pihak-pihak lain sebagai contoh kepada umum, pemerintah daerah, dan pihak-pihak terkait." (Hasil Wawancara, September 2016)

Seperti ungkapan di atas, pertanggungjawaban Bidang Kebersihan dan Pertamanan antara lain adalah tentang penanganan sampah Bidang Kebersihan dan Pertamanan kepada pihak-pihak lain. Pertanggungjawaban Bidang Kebersihan dan Pertamanan terlihat dari pendapat Kasie Persampahan sebagai berikut : "Yang jelas pertama membantu masyarakat dalam penanganan sampah di Kabupaten Subang, serta menjadikan Kabupaten Subang menjadi kawasan yang bersih, sehat dan bebas sampah." (Hasil Wawancara, September 2016)
Pendapat di atas menunjukkan dalam pelaksanaanya, Bidang Kebersihan dan Pertamanan sebagai lembaga pengelolaan kebersihan di Kabupaten Subang, tetapi juga kembali kepada masyarakat.Namun Bidang Kebersihan dan Pertamanan juga memikirkan masyarakat terutama kebersihan di Kabupaten Subang.Semua itu bertujuan untuk meningkatkan kebersihan masyarakat Kabupaten Subang.

Akuntabilitas dalam penanganan sampah dapat diartikan sebagai banyak pertanggung jawaban atas penyelenggaraan pelayanan kepada pihak yang memiliki hak dan wewenang untuk meminta pertanggung jawaban tersebut.Pertanggung jawaban Bidang Kebersihan dan Pertamanan dalam penanganan sampah bertanggung jawab kepada pemerintah Kabupaten Subang.

Dapat disimpulkan bahwa akuntabilitas Bidang Kebersihan dan Pertamanan dalam penanganan sampah baik.Dilihat dari penanganan sampah dapat didukung dari Pemerintah sehingga dalam pelaksaannya Bidang Kebersihan dan Pertamanan dapat terlaksana dengan baik.

\section{Unsur-unsur yang menjadi kendala Kinerja Bidang Kebersihan dan Pertamanan Dinas Tata Ruang Permukiman dan Kebersihan dalam Menangani Sampah di Kabupaten Subang}

Berdasarkan hasil penelitian dilapangan, terdapat unsur-unsur yang menjadi kendala dalam Kinerja Bidang Kebersihan dan Pertamanan 
Dinas Tata Ruang Permukiman dan Kebersihan dalam menangani sampah di Kabupaten Subang, sebagai berikut :

1. Sarana dan Prasarana

Sarana dan Prasarana merupakan salah satu faktor yang mempengaruhi dalam penanganan sampah di Kabupaten Subang. Karena penilaian terhadap kinerja penanganan sampah dari kondisi sarana dan prasarana persampahan, meliputi jumlah TPS atau kontainer, waktu pengumpulan sampah, alat pengangkutan sampah masih dirasakan kurang.

2. Pertumbuhan Penduduk

Pertumbuhan Penduduk juga merupakan salah satu unsur yang mempengaruhi dalam penanganan sampah di Kabupaten Subang.Karena semakin meningkat jumlahpenduduk, perubahan pola konsumsi dan gaya hidup masyarakat di Kabupaten Subang maka semakin bertambah jumlah sampah yang ditimbulkan.

\section{SIMPULAN}

Berdasarkan hasil analisis dan pembahasan yang dilakukan, dapat ditarik beberapa kesimpulan mengenai Kinerja Bidang Kebersihan dan Pertamanan Dinas Tata Ruang Permukiman dan Kebersihan dalam penanganan sampah di Kabupaten Subang, sebagai berikut :

1. Kinerja Bidang Kebersihan dan Pertamanan Dinas Tata Ruang Permukiman dan Kebersihan dalam menangani sampah di Kabupaten Subang secara umum belum optimal. Hal ini dapat dilihat dari belum optimalnya pelayanan pengangkutan sampah secara keseluruhan hal ini dikarenakan kurangnya armada/kendaraan angkutan
3. Partisipasi Masyarakat

Masih rendahnya peran serta masyarakat dalam penanganan sampah menjadi salah satu faktor yang mempengaruhi dalam penanganan sampah.Karena masih rendahnya jumlah sampah yang terangkut ke TPA juga disebabkan oleh rendahnya kesadaran masyarakat dalam mendukung penanganan sampah di Kabupaten Subang. Hal ini dapat dilihat dari masih banyak masyarakat yang membuang sampah sembarangan, sehingga menjadi beban petugas kebersihan pada saat proses pengangkutan sampah.

Rendahnya kesadaran masyarakat terhadap penanganan sampah tersebut, dapat disebabkan karena pengetahuan terhadap pola penanganan sampah masih rendah, maupun kurangnya penyuluhan tentang masalah persampahan.

sampah, jumlah volume sampah yang terangkut ke Tempat Pembuangan Akhir (TPA), jangkauan pelayanan pengelolaan sampah masih terbatas pada jalanjalan utama. Aspek-aspek untuk mengukur keberhasilan kinerja Bidang Kebersihan dan Pertamanan dalam menangani sampah di Kabupaten Subang adalah Produktivitas, Kualitas Layanan, Reponsivitas, Responsibilitas, dan Akuntabilitas.

2. Unsur-unsur yang menjadi kendala Kinerja Bidang Kebersihan dan Pertamanan Dinas Tata Ruang Permukiman dan Kebersihan dalam menangani sampah di Kabupaten Subang adalah sarana dan prasarana, 
pertumbuhan penduduk serta partisipasi masyarakat.

\section{DAFTAR PUSTAKA}

BabanBagong, Suyanto, 2005. MetodePenelitianSosial :BerbagaiAlternatif Media.

$$
\text { Pendekatan.Jakarta :Prenada }
$$

Bastian, Indra, 2001. AkuntansiSektorPublik $d i$

Indonesia,CetakanPertama, Yogyakarta, BPFE..

Dwiyanto, Agus. 2002. Mewujudkan Good Governance MelaluiPelayanan Press. Publik, Yogyakarta : UGM

EffendyMarihotTua, 2002. ManajemenSumberDayaManusia. Jakarta : Grasindo Mahmudi. 2005.

ManajemenKinerjaSektorPublik.

UPPP. AMP YKPN :

$$
\text { Yogyakarta }
$$

Mahsun, Muhamad. 2009. PengukuranKinerjaSektorPublik. BPPE : Yogyakarta
Mejia, Dkk. 2007.Managing Human Resource Edition. Pearson Education : New

$$
\text { Jersey }
$$

Meleong, Lexy. 2000. MetodologiPenelitianKualitatif.Band ung : PT. Remaja

$$
\text { RosadaKarya }
$$

Monday, and Noe. 1993. Human Resource Management. A Division At Simon and

Schuster, Inc : USA

Publik, Gradi. 2010. EvaluasiKinerja SDM. T RefikaAditama :Bandnung Prajudi, Armosudiro. 2006. EvaluasiKinerja SDM.Bandung :Refika, Aditama.

Sedarmayanti. 2001. SumberDayaManusiadanProduktivit asKerja,Bandung :

$$
\text { MandarMaju. }
$$

Surjadi. 2009.

PengembanganKinerjaPelayananPu blik. Bandung :Refika

$$
\text { Aditama. }
$$

Wibowo. 2010.ManjaemenKinerja. Jakarta. Penerbit :RajagrafindoPersada. WinaSanjaya. 2002. MetodologiPenelitianPendidikan, Bandung, San Grafika. 